\title{
A HERMENÊUTICA CONSTITUCIONAL DO STF QUANTO À AMPLITUDE DO PRINCÍPIO DA VEDAÇÃO AO CONFISCO TRIBUTÁRIO
}

\author{
Valmir César Pozzetti* \\ Helton Carlos Praia de Lima**
}

SUMÁRIO: Introdução; 2 Limitação ao poder de tributar; 3 Vedação à tributação com objetivo confiscatório; 4 A visão do STF quanto à amplitude do princípio da vedação ao confisco; 5 Considerações finais; Referências.

RESUMO: O objetivo desta pesquisa foi o de analisar a interpretação hermenêutica do Supremo Tribunal Federal (STF) quanto à amplitude do princípio constitucional da vedação ao confisco, utilizando como referência as decisões contidas no site da Suprema Corte, no período de outubro de 1988 a janeiro de 2018. Para tanto, localizaram-se os julgados relacionados ao tema, identificaram-se os principais argumentos e a quantidade de decisões favoráveis e desfavoráveis. A metodologia utilizada foi a do método indutivo; quantos aos meios a pesquisa foi a bibliográfica e documental e quanto aos fins foi a quantitativa. Registrou-se como resultado que são poucas as demandas questionando a vedação ao confisco em relação às demais questões tributárias e que as normas referentes à aplicação da multa tributária não violam o princípio pesquisado, representando $64 \%$ das decisões favoráveis ao ente público. A conclusão a que se chegou foi a de que o positivismo jurídico ainda influencia as decisões, embora haja espaço para novas reflexões em outras demandas.

PALAVRAS-CHAVE: Tributário; Confisco; Vedação; Hermenêutica; Jurisprudência.

\section{THE CONSTITUTIONAL HERMENEUTICS OF THE SUPREME COURT WITH REGARD TO THE BROADNESS OF THE PRINCIPLE OF TRIBUTARY CONFISCATION PROHIBITION}

ABSTRACT: Current research analyzes the hermeneutic interpretation of the Supreme Court of Justice with regard to the broadness of the constitutional principle of confiscation prohibition. Decisions retrieved from the Supreme Court site between October 1988 and January 2018 are investigated. Judgments related to the

\footnotetext{
Docente Adjunto da Universidade do Estado do Amazonas. Docente Adjunto da Universidade Federal do Amazonas; Doutor em Direito Ambiental pela Universidade de Limoges/França. Brasil.

E-mail:v_pozzetti@hotmail.com

${ }^{*}$ Chefe de Departamento de Direito Privado, Docente Adjunto Universidade Federal do Amazonas e Universidade do Estado do Amazonas. Brasil.
} 
theme were pinpointed and the main arguments and the number of favorable and unfavorable decisions were identified. Induction and bibliographical and documental research were employed. Results show that demands against the confiscation bar are few when compared to other tributary issues. Further, the norms on the application of fines do not violate the principle under analysis. In fact, $64 \%$ of decisions were favorable to the public enterprise. In fact, juridical positivism still affects decisions even though there are other means for novel discussions with other demands.

KEY WORDS: Taxes; Confiscation; bar; Hermeneutics; Jurisprudence.

\section{LA HERMENÉUTICA CONSTITUCIONAL DEL STF CUANTO A LA AMPLITUD DEL PRINCIPIO DEL BLOQUEO AL CONFISCO TRIBUTARIO}

RESUMEN: El objetivo de esta investigación fue el de analizar la interpretación hermenéutica del Supremo Tribunal Federal (STF) en lo que se refiere a la amplitud del principio constitucional del sellado al confisco, utilizando como referencia las decisiones contenidas en el sitio de la Suprema Corte, en el período de octubre de 1988 a enero de 2018. Para esto, se localizaron los juzgados relacionados al tema, se identificaron los principales argumentos y la cuantidad de decisiones favorables y desfavorables. La metodología utilizada fue la del método inductivo; cuantos a los medios la investigación fue la bibliográfica y documental y en lo que refiere los fines, fue la cuantitativa. Se ha registrado como resultado que son pocas las demandas cuestionando del sellado al confisco en relación a las demás cuestiones tributarias y que las normas referentes a la aplicación de la multa tributaria no violan el principio investigado, representando el $64 \%$ delas decisiones favorables al ente público. La conclusión la que se ha llegado fue la de que el positivismo jurídico aún influencia las decisiones, aunque haya espacio para nuevas reflexiones en otras demandas.

PALABRAS CLAVE: Tributario; Confisco; Sellado; Hermenéutica; Jurisprudencia.

\section{INTRODUÇÃO}

A hermenêutica é a ciência que leva à orientação na interpretação da norma com o objetivo de determinar o sentido e a amplitude das expressões jurídicas, ou seja, o estado da arte de interpretar. Nesse sentido, a ciência jurídica se dedica à sistematização dos métodos de interpretação das normas, de maneira a torná-las compreensíveis, ou seja, buscar o sentido verdadeiro da regra em abstrato para depois analisar seu alcance e sua extensão no caso concreto.

Embora a hermenêutica jurídica tenha como propósito tornar mais 
compreensível as normas, não há consenso na doutrina quanto à interpretação constitucional da diferença entre princípio e regra. O que se sabe é que o princípio e a regra usufruem do mesmo status de norma jurídica e que não há hierarquia entre eles para o intérprete. Entretanto, algumas diferenças são apontadas, como o conteúdo, a estrutura normativa e as particularidades da aplicação.

Em relação às regras tributárias, têm-se proposições normativas aplicáveis sob a forma de tudo ou nada. Deve incidir de modo direto e automático produzindo efeitos, sendo sua aplicação por subsunção, a menos que seja inválida, haja outra mais específica ou não esteja em vigor. Contudo, tanto a regra como o princípio podem ser ponderados diante do caso concreto.

Em relação aos princípios tributários, contém maior carga valorativa, fundamento ético, decisão política relevante, indicando determinada direção a seguir. Assim, no caso de conflito com outro princípio, deve-se atribuir uma valoração de peso e importância, de maneira que a escolha do princípio se dê de forma fundamentada e mediante ponderação.

Neste contexto, na criação de uma lei tributária, deve-se respeitar os princípios constitucionais gerais aplicáveis a todos os ramos do direito, como também os específicos do direito tributário. A inobservância de princípios e regras, como os direitos e garantias constitucionais e as limitações ao poder de tributar, torna a norma ilegal e inconstitucional, passível de transgressão pelo contribuinte.

A despeito de a Constituição brasileira de 1988 estabelecer aos entes públicos capacidade para instituir e cobrar tributos, igualmente determina certas limitações de competência. Desse modo, os princípios de direito tributário impõem limitações ao poder de tributar do Estado, por isto, não é sem propósito que se encontram redações nas normas constitucionais/legais com as expressões: "é vedado à União, aos Estados, ao Distrito Federal e aos Municípios [...]”.

Este controle de aplicação da melhor hermenêutica em sintonia com os propósitos constitucionais é feito, em última análise, pelo Supremo Tribunal Federal (STF), que exerce o papel de guardião da Constituição, atribuição dada pelo Poder Constituinte, representante da soberania popular. Desse modo, todo excesso que ameace as diretrizes traçadas pela Lei Maior deve ser excluído, inclusive o excesso de tributação sobre os bens e direitos do contribuinte, caracterizado com confisco tributário.

Importante destacar que o contribuinte tem obrigações, como recolhimento de diversos tributos, declarações e prazos legais para o cumprimento das obrigações 
tributárias. Uma vez não honrados, acarretam penalidades pecuniárias expressivas, que podem afetar os recursos financeiros. Todavia, possui como garantia os princípios constitucionais e legais que limitam o poder de tributar e asseguram uma sociedade livre, justa e solidária; bem como a liberdade, a segurança e a propriedade individual, garantindo uma vida digna e, ainda, a possibilidade de arguição de injustiças perante o poder judiciário.

Neste contexto, a Constituição brasileira veda a utilização do tributo com efeito de confisco, entretanto, o poder público ao criar normas tributárias, muitas vezes não se preocupa com a capacidade contributiva do sujeito passivo ao aplicar penalidades administrativas sem considerar o tamanho do capital do contribuinte, seu faturamento ou capacidade econômica.

Ao estabelecer valores absolutos ou percentuais sem levar em consideração a individualização do contribuinte nas infrações tributárias, o poder executivo iguala desiguais, com possibilidade de incorrer em atos confiscatórios de patrimônio particular e atentar contra a dignidade da pessoa humana. Assim, cabe ao poder judiciário, por intermédio do controle de constitucionalidade, em nome da segurança jurídica e em respeito ao Estado democrático de Direito, anular o ato e restaurar a ordem jurídica social.

Desta forma, a problemática que se levanta nesta pesquisa é de que forma o ente público pratica a limitação imposta pelo princípio constitucional da vedação ao confisco, no olhar do STF?

A pesquisa se justifica em virtude de a que, pelo fato de a Constituição Federal brasileira de 1988 ter por base o Estado democrático de Direito, tem-se a igualdade formal, material e a consonância com os princípios constitucionais, sendo a democracia a realização de valores de igualdade, liberdade e dignidade da pessoa, tanto como direito como dever, que devem ser respeitados por todos.

Com intuito de responder ao questionamento em foco, tem-se como objetivo, nesta pesquisa, examinar como o STF interpreta as ações judiciais relativas à vedação ao confisco e, especificamente, localizar as decisões quanto ao tema, identificar os principais argumentos e a quantidade de decisões favoráveis e desfavoráveis.

Para tanto, a metodologia que se adotou na presente pesquisa foi o método indutivo; quanto aos meios a pesquisa bibliográfica documental e quanto aos fins, análise quantitativa, para a análise das decisões constantes do site de STF, no período de outubro de 1988 a janeiro de 2018, sobre os julgados onde constam o 
termo "vedação ao confisco" e que tratam de impostos, contribuições sociais, taxas, execução fiscal, multas, depósito judicial e empréstimo compulsório, excluindo os demais, como os valores de restituição, pelo motivo de não fazerem parte ou de terem resultados insignificantes para a pesquisa.

A estrutura da pesquisa tem em primeiro plano uma breve abordagem sobre a limitação ao poder de tributar. Na sequência, relata-se sobre a vedação ao confisco, fazendo uma abordagem quanto à ação ser princípio jurídico ou regra. Em continuidade, enuncia-se a visão do STF quanto à amplitude do princípio da vedação ao confisco, após, relatam-se as considerações finais, por fim as referências.

\section{LIMITAÇÃO AO PODER DE TRIBUTAR}

O direito moderno caracteriza-se pelo respeito à Constituição e às garantias individuais e coletivas. É dever do Estado prestar serviços públicos de qualidade, necessitando para isso de recursos financeiros, que são arrecadados dos cidadãos por intermédio dos tributos. Neste sentido, os sistemas de garantias constitucionais exigem tributação compatível com o Estado democrático de Direito e observância ao princípio da dignidade da pessoa humana.

Observa Sousa Júnior que a cobrança de tributo pelo Estado tem respaldo constitucional e legal, bem como, faz-se necessária para a preservação dos direitos constitucionais garantidos à sociedade ${ }^{03}$. Todavia, o princípio constitucional da vedação ao confisco surge como limite ao poder de tributar e torna ilegítima a redução da vida do contribuinte à situação de necessidade e sacrifício.

Neste sentido, enuncia Teixeira que o Estado moderno trouxe o conceito de capacidade contributiva, forçando o poder público reduzir a carga tributária sobre os mais pobres. Como resultado, no estágio atual tem-se a tributação progressiva com alíquota maior para quem detém melhor capacidade contributiva ${ }^{04}$.

A modernidade é representada pelo avanço tecnológico e científico, pela concentração dos meios de produção do sistema capitalista predominante no mundo globalizado, pelo monopólio institucional do Estado, inclusive na produção de normas jurídicas que regulam a sociedade. É o que Santos e Ferreira afirmam ao apontarem que o ente público e suas políticas sociais surgem para garantir

\footnotetext{
03 SOUSA JÚNIOR, Mamede Rodrigues de. Princípio da vedação ao confisco: uma interpretação hermeneuticamente adequada e crítica à jurisprudência do Supremo Tribunal Federal, Brasília, 2015, p. 23. Disponível em: https://scholar.google.com.br/. Acesso em: 1 set. 2016.

${ }^{04}$ TEIXEIRA, Anderson Vichinkeski. O tributo na formação histórica do Estado moderno. Revista de Direito Tributário da APET, São Paulo, v. 12, p. 13-44, 2007.
} 
segurança, bem-estar e reduzir a incerteza do cotidiano da sociedade ${ }^{05}$.

Todavia, estas garantias sociais geram custos à máquina estatal e são dependentes do modelo de estrutura administrativa adotada pelo Estado, se de intervenção maior ou menor na sociedade. De qualquer modo, sempre haverá insatisfação quanto ao montante para o financiamento da máquina estatal e da distribuição adequada dos serviços públicos à sociedade. Satisfatório ou não, o certo é que existe um liame entre a receita advinda dos tributos e os rumos que a sociedade deseja que o Estado observe ou siga.

A exigência de tributos deve considerar a dignidade da pessoa humana, a vida, a liberdade e a propriedade. Neste sentido, o Estado dDemocrático de Direito requer custo financeiro a garantir as políticas públicas em busca do ideal de igualdade material e diminuir a desigualdade econômica e social. Assim, a função da tributação é garantir ao Estado os recursos financeiros para realizar as políticas sociais e garantir os direitos fundamentais, inclusive a distribuição de riqueza, respeitando a capacidade contributiva ou econômica na cobrança do tributo e evitando punir os detentores, notadamente, de menor capacidade de pagar o encargo.

Para Bobbio, o Estado moderno é resultante do processo de obtenção de certas liberdades, dentre elas a garantia da vedação ao confisco pelo poder do soberano, que tende a ser o núcleo de partida dos direitos humanos ${ }^{06}$.

Nesse sentido, aponta Canotilho que o reconhecimento dos direitos humanos pela Constituição os transformam em direitos fundamentais, munidos da coercitividade das normas do direito elaborado pelo Estado ${ }^{07}$.

Outra opinião a ser observada é de Caliendo, que alerta que a busca da eficácia da proteção dos direitos fundamentais sociais não pode ser feita como uma decisão alheia às situações históricas e sociais da implantação destes direitos, que devem atentar para determinados limites em sua proteção ${ }^{08}$. Assim, deve-se evitar os abusos camuflados de direitos sociais, como benefício a quem não precisa ou destoante do propósito legal, a exemplo da tributação em excesso para justificar

05 SANTOS, Boaventura de Sousa; FERREIRA, Silva. A reforma do Estado-Providência entre globalizações conflituantes, in Pedro Hespanha e Graça Carapinheiro (org.), Risco social e incerteza: pode o Estado social recuar mais?. Porto, Afrontamento, 2003, p. 33. Disponível em: https://scholar.google.com.br/. Acesso em: 19 fev. 2018.

${ }^{06}$ BOBBIO, Norberto. Liberalismo e democracia. 6. Ed. Brasiliense: São Paulo, 1994, p. 11-13.

${ }^{07}$ CANOTILHO, Direito Constitucional. Ed. Coimbra: Almedina, 1993, p. 497.

${ }^{08}$ CALIENDO, Paulo Reserva do possível, direitos fundamentais e tributação. In: SARLET, Ingo Wolfgang: TIMM, Luciano Benetti (org.). Direitos fundamentais: orçamento e "reserva do possível". 2. Ed. Porto Alegre: Livraria do Advogado, 2013, p. 178. 
financiamento à saúde, dentre outros.

De outra forma, a capacidade para instituir tributos, concedida pela Constituição brasileira de 1988 aos entes da federação, União, Estados, Distrito Federal e municípios (art. 145), encontra limites, nas áreas de atuação de cada ente político, que resguardam valores relevantes como os direitos e garantias individuais e coletivos (art. $5^{\circ}$ e incisos), assegurando o direito à propriedade, à igualdade, ao trabalho, a obter informações legais do poder público, à defesa de direitos e contra ilegalidade e abuso de poder, entre outros mais.

Pode-se dizer que o conjunto dos princípios e normas que regem os limites da competência tributária se refere às limitações ao poder de tributar, que se desdobram nos princípios constitucionais tributários e nas imunidades (arts. 150 a $152 \mathrm{da} \mathrm{CF} / 88^{\circ 9}$ ), bem como outros tipos normativos, como leis complementares, resoluções do senado, convênios, de maneira a balizarem o poder do legislador em relação à criação ou à modificação de tributos.

As limitações ao poder de tributar sugerem respeito e obediência às normas constitucionais e infraconstitucionais. Desta maneira, integram o conjunto de características que compõem o campo, o modo, a forma e a intensidade de atuação do poder dos entes federativos. Porém, as limitações não devem ser consideradas barreiras ao exercício da competência tributária, ou supressão da competência. Em vista disso, se o ente público ultrapassar sua capacidade ou ferir preceitos constitucionais, exerce competência tributária que não lhe foi autorizada.

Um dos principais princípios constitucionais é o da legalidade tributária, pois é vedado aos entes públicos exigir ou aumentar tributo sem lei que o prescreva (art. 150, I, CRFB/88). Compreende os ideais de justiça e de segurança jurídica, valores que garantem os direitos fundamentais e freiam as imposições tributárias da administração pública. Com base na legalidade tributária, é mister que a lei defina in abstrato a relevância para que in concreto se possa definir o contribuinte, a base de cálculo, a alíquota, o ente tributante e o fato gerador, dentre outras especificidades.

Quanto ao aplicador da lei, é defeso fazer uso de interpretações extensivas e de analogia que se mostrem incompatíveis com a tipicidade e determinação do tributo. É o que menciona o Código Tributário Nacional (CTN), quanto ao princípio da legalidade (art. 97), ao estabelecer que somente a lei pode instituir tributos ou extingui-los, majorá-los ou reduzi-los. São matérias postas sob reserva da lei a definição do fato gerador da obrigação tributária, o sujeito passivo, a fixação de

\footnotetext{
${ }^{09}$ BRASIL. Constituição da República Federativa do Brasil de 1988. Brasília, DF: Poder Executivo. 1988.
} 
alíquota e da base de cálculo, a cominação de penalidades tributárias, as situações que expressam a suspensão da exigibilidade ou de extinção do crédito tributário e os institutos da anistia e da isenção.

No entender de Cassone ${ }^{10}$, a Constituição, também, registra as limitações ao poder de tributar nos arts. 150 a 152 . Tais limitações são estabelecidas por princípios como o da legalidade, da igualdade, da vedação ao confisco etc., e revelam garantias fundamentais do contribuinte de serem tributados dentro de parâmetros constitucionais estabelecidos.

$\mathrm{Na}$ mesma linha de raciocínio, Chimenti ${ }^{11}$ reconhece que a competência tributária encontra limites na Constituição Federal e no Código Tributário Nacional (arts. $9^{\circ}$ a $11^{12}$ ), intitulados como princípios jurídicos da tributação e das limitações ao poder de tributar, tais como o da legalidade, da anterioridade da lei, isonomia ou do respeito à capacidade contributiva, uniformidade tributária, não limitação do tráfego, exclusividade dos impostos, não transferência da competência tributária, interpretação literal da legislação que disponha sobre outorga de favores fiscais e dispensa de obrigações tributárias acessórias, irretroatividade da lei tributária, inversão do ônus da prova, imunidade tributária e vedação ao confisco. Este último objeto de análise da pesquisa.

\section{VEDAÇÃO À TRIBUTAÇÃO COM EFEITO CONFISCATÓRIO}

A Constituição brasileira de 1988 surgiu num processo de transição do regime militar, com direitos limitados, para um regime garantista dos direitos sociais mais amplos e com mais liberdade civil e política. Embora o momento proporcione melhores condições à população, os atos dos indivíduos e do próprio ente público ainda necessitam de exame pelo poder judiciário sempre que se questiona possíveis violações à ordem social, mesmo que em menor intensidade.

É inegável a interferência do poder judiciário sobre atos do executivo e legislativo, quando necessária a reparação de possíveis excessos nas políticas públicas e verificando a harmonização dos feitos aos preceitos constitucionais. Todavia, devese atentar para a relevância da hermenêutica jurídica como argumento de limitação da conduta do juiz, no sentido de tornar viável a aplicação da Constituição, com a cautela

\footnotetext{
${ }^{10}$ CASSONE, Vittorio. Direito tributário. 11. ed. São Paulo: Atlas, 1999, p. 99-100.

${ }^{11}$ CHIMENTI, Ricardo Cunha. Direito tributário. São Paulo: Saraiva, 2001, p. 10.

${ }^{12}$ BRASIL. Lei $\mathrm{n}^{0}$ 5.172, de 25 de outubro de 1966. Código tributário Nacional. Brasília, DF: Poder Executivo. 1966.
} 
devida para não gerar injustiça ou arbitrariedade, tampouco, possibilitar a aplicação dos textos legais, conforme sua conveniência, em especial, os relativos ao direito tributário. É o que aponta Canotilho's não dá ao poder estatal liberdade de ação, como também sua discricionariedade está adstrita aos princípios constitucionais.

A hermenêutica jurídica tradicional, predominante no Brasil, tem por base o senso comum teórico dos juristas, que reúne várias teorias sobrepostas, com objetivo de encontrar um critério claro e uniforme de formulação teórica. Em outras palavras, como enunciam Souza e Dias ${ }^{14}$, a hermenêutica como ciência jurídica se dedica ao estudo, à formação, à sistematização dos métodos e regras do processo de interpretação das normas, visando a melhor aplicação ao caso concreto e a satisfação na solução do problema.

A interpretação das normas ao caso concreto a solucionar nem sempre é tarefa fácil e consensual. Para Barroso e Barcellos ${ }^{15}$, na diferença entre princípios e regras, em especial às potencialidades para interpretação constitucional, há pelo menos um consenso na doutrina, a saber que o princípio e a regra usufruem do mesmo status de norma jurídica e compõem sem hierarquia o sistema referencial do intérprete, embora haja diferenças no conteúdo, na estrutura normativa e nas particularidades da aplicação.

No sentido de orientar o intérprete na distinção entre princípios e regras, Dworkin aponta que as regras devem adotar forma "tudo-ou-nada", significando que a regra não pode ser relativizada, dando a ideia de ter efeito ou não ter ${ }^{16}$. Então, no caso de divergência de conflitos, uma regra deve dar lugar para o emprego de outra por impossibilidade da convivência de regras contraditórias para o mesmo fato. Deste modo, a solução trazida pelo ordenamento jurídico na escolha da melhor regra em desfavor da outra pode ter por base os critérios de temporalidade, hierarquia ou especificidade.

Contudo, ao contrário das regras, os princípios conflitantes podem se compatibilizarem, juntando as forças correspondentes de cada um deles, o que certifica que o caráter do princípio da vedação ao confisco, apesar de rejeitar a

${ }^{13}$ CANOTILHO, José Joaquim Gomes. Constituição Dirigente e Vinculação do Legislador, Coimbra: Ed. Cimbra, 1982, p. 74 .

${ }^{14}$ SOUZA, Carolina Romero de; DIAS, Eduardo Rocha. Nova hermenêutica constitucional: a valorização dos princípios na interpretação constitucional da previdência social brasileira. Revista Direito \& Dialogicidade, v. 3, n. 1, 2013.

${ }^{15}$ BARROSO, Luís Roberto; BARCELLOS, Ana Paula de. O começo da história. A nova interpretação constitucional e o papel dos princípios no direito brasileiro. Revista de direito administrativo, v. 232, p. 141-176, 2003. Disponível em: https://scholar.google.com.br/. Acesso em: 19 fev. 2018.

${ }^{16}$ DWORKIN, Ronald. Levando os direitos a sério. São Paulo: Martins Fontes, 2002, p.39-42. 
combinação dos princípios por intermédio de fórmula, leva em consideração os elementos importantes para a solução do problema. Para Alexy,

A colisão entre princípios deve ser solucionada de forma diferente das regras. Um dos princípios terá que ceder, embora não se torne inválido ou excluído. Haverá apenas uma precedência do escolhido com maior peso sobre 0 outro conforme requer a condição do caso concreto. Tratase de dimensão do peso do princípio ao caso concreto. Diferentemente, do conflito entre regras que se dá no âmbito da validade, onde a outra será excluída ou inválida. ${ }^{17}$

A breve análise da equação de Alexy, quanto à discricionariedade do intérprete, enseja o subjetivismo e a unilateralidade, quando qualifica as circunstâncias concretas ao caso e confere valores aos princípios, assim, demonstra sua intenção e destrói o propósito da equação, que é a neutralidade, cientificidade e impedir a subjetividade da decisão. Neste contexto, Dworkin esclarece que

O princípio da vedação ao confisco não deve ser usado com uma fórmula rigorosa, pois a escolha dos componentes seria de modo isolado pelo intérprete. Assim, deve-se ter a ideia de imparcialidade do direito onde as proposições jurídicas sejam verdadeiras e provenham dos princípios de justiça, equidade e devido processo legal, dando melhor leitura construtiva da prática jurídica à sociedade. A plenitude do direito é tanto o produto da interpretação abrangente da prática jurídica quanto sua fonte de estímulo. ${ }^{18}$

Deste modo, o princípio da vedação ao confisco tem por base o sistema de proteção constitucional ao contribuinte e evita os excessos ao poder de tributar do Estado, como a obrigatoriedade de aprovação de lei, necessidade de processo administrativo de lançamento fiscal e tantos mais. A legislação tributária com base na Constituição indica as situações hipotéticas para o pagamento do tributo, o conceito de renda, prestação de serviços, as hipóteses de propriedade de bem, dentre outros. Ocorrido o fato gerador previsto na lei a autoridade fiscal tem o dever de realizar o

\footnotetext{
${ }^{17}$ ALEXY, Robert. Teoria dos direitos fundamentais. 2. Ed. São Paulo: Malheiros, 2008, p. 93-94.

${ }^{18}$ DWORKIN, Ronald. O império do direito. São Paulo: Martins Fontes, 2007, p. 272-273.
} 
lançamento tributário, por ser ato vinculado.

Assim, a lei elaborada pelo poder legislativo definirá o fato gerador do tributo, a base de cálculo, alíquota a ser aplicada, responsável pelo pagamento, forma de fiscalização e demais obrigações necessárias para o cumprimento da norma pelo poder executivo, tudo de conformidade com o texto constitucional.

Pode-se registrar que as normas que criam, fixam limites mínimos e máximos e a forma de cobrança de tributos têm natureza de regra, exigida na forma do tudo-ou-nada, não admitindo interação entre as regras conflituosas, todavia, devem respeitar o mínimo existencial e a dignidade da pessoa do contribuinte para não violarem o princípio da vedação ao confisco como instrumento de controle constitucional e de inibição do excesso do poder normativo.

De outro modo, regras podem entrar em divergência com princípios no caso de excesso e oneração demasiada ao mínimo existencial e a dignidade da pessoa do contribuinte. Nesse caso, a regra deve ser repelida pela utilização direta do princípio, garantindo a vontade da norma constitucional. Assim, os princípios se fazem importantes e relevantes, pois servem de certificação ao intérprete do direito para definir o que é confiscatório ou não.

Quanto às regras existentes anteriores à Constituição de 1988, Tepedino faz crítica, registrando que ideias e valores ultrapassados, às vezes, continuam em vigor e firmes nos conhecimentos jurídicos do intérprete, dificultando a assimilação das modificações conduzidas pela nova ordem constitucional e provocando interpretações com base no ordenamento constitucional desatualizado, induzindo a práticas jurídicas contrárias à Constituição e abalando a hermenêutica jurídica ${ }^{19}$.

Registra, ainda, que a tradicional diferença entre os direitos público e privado perde força, ganhando corpo a ideia de separação entre as relações jurídicas patrimoniais e existenciais, com ascensão da última. Nesse sentido, apesar de ser um direito fundamental a propriedade não tem natureza absoluta e pode ser relativizada em sintonia com os demais direitos constitucionais, até mesmo os de caráter social ${ }^{20}$.

Em consonância com o entendimento, Sarlet registra que a dignidade da pessoa é um princípio absoluto e não pode ser renunciado, pois é imprescindível. Dessa forma, mesmo preponderante sobre os demais princípios e regras, não há como afastar a relativização ou convivência harmônica em respeito a igual dignidade

\footnotetext{
19 TEPEDINO, Gustavo. Normas constitucionais e relações de direito civil na experiência brasileira. Temas de direito civil. t. 2. Rio de Janeiro: Renovar, 2006, p. 25 e 32.

${ }^{20}$ Idem, p. 25 e 32.
} 
dos seres humanos ${ }^{21}$.

Em outro contexto, para se medir a intensidade do ato de confisco, Horvath sugere o uso da proporcionalidade e razoabilidade, considerando a ponderação dos princípios e a análise dos critérios como as condições de tempo, lugar, fins econômicos e sociais do tributo, no caso concreto, observando que a tributação confiscatória dificulta a situação financeira do contribuinte ${ }^{22}$.

O princípio da vedação ao confisco se vincula ao princípio constitucional da capacidade contributiva e objetiva regular o valor do tributo às características dos contribuintes. Em outras palavras, entende-se por capacidade contributiva a parte dos rendimentos remanescentes após os gastos com as despesas de subsistência ou necessidades básicas do contribuinte e seus dependentes, sendo uma espécie de imunidade sobre o mínimo existencial e garantia da dignidade pessoa. Para Zilveti,

A capacidade contributiva é sinônimo de capacidade econômica, pois se refere a divisão equitativa das despesas públicas, onde cada cidadão assume o encargo tributário proporcional às suas expectativas financeiras. Assim, a capacidade contributiva ou econômica estaria associada à compreensão de justiça tributária, de distribuição equilibrada dos encargos sociais, não atingindo o mínimo existencial. ${ }^{23}$

Nessa linha de raciocínio, Baleeiro registra que a capacidade contributiva ou econômica dá a noção de que o indivíduo deve contribuir com as despesas do Estado conforme suas posses financeiras ${ }^{24}$.

Assim, tem-se como coerente a afirmação de Horvath ao apontar ser o confisco um excesso de violação à capacidade contributiva ${ }^{25}$. Na mesma direção Domingues lembra que a capacidade contributiva tem vínculo direto com a igualdade, no sentido de proporcionalidade, na arrecadação do custeio pelo Estado

\footnotetext{
${ }^{21}$ SARLET, Ingo Wolfgang. Dignidade da pessoa humana e direitos fundamentais na Constituição Federal de 1988. 9. ed. rev. atual. Porto Alegre: Livraria do Advogado, 2012, p. 89.

${ }^{22}$ HORVATH, Estevão. O princípio do não-confisco no direito tributário. São Paulo: Dialética, 2002, p. 60.

${ }^{23}$ ZILVETI, Fernando Aurélio. Princípios de direito tributário e a capacidade contributiva. São Paulo: Quatier Latin, 2004, p. 134-135.

${ }^{24}$ BALEEIRO. Aliomar. Limitações constitucionais ao poder de tributar. 7. ed. Rio de janeiro: Forense, 2006, p. 537.

${ }^{25}$ HORVATH, Estevão. O princípio do não-confisco no direito tributário. São Paulo: Dialética, 2002, p. 23.
} 
para efetivar as garantias constitucionais reivindicadas pela sociedade ${ }^{26}$.

No entendimento de Ávila,

Deve ser encontrada uma harmonização entre os poderes público e privado na definição da carga tributária. A proteção do direito à vida, à dignidade e à garantia dos direitos fundamentais de liberdade fundamentam a defesa contra restrições injustificadas do Estado nos bens jurídicos privados, como exigem medidas efetivas para a proteção desses bens. A ideia é proibir a tributação ao mínimo existencial do indivíduo ante a atos supostamente confiscatórios do ente público. ${ }^{27}$

No tocante à interpretação do STF sobre o princípio da vedação ao confisco, Sousa Júnior aponta que a Suprema Corte ainda é influenciada pelo positivismo jurídico nas suas decisões ${ }^{28}$. No mesmo sentido Bobbio comenta que o positivismo e o seu conceito autoritário do direito têm por base a concepção estatal do direito ${ }^{29}$.

Neste contexto, a hermenêutica tradicional, quanto à aplicação do princípio à vedação do confisco, tende a inclinar-se ao positivismo jurídico, pois a interpretação e aplicação do direito, bem como os atos normativos do Estado, representados pelos poderes legislativo e executivo, são direcionados e subordinados à fonte do direito predominante, que é a lei, como questionado por parte de doutrinadores, a exemplo dos citados.

Para Streck, o positivismo deixa margem para a discricionariedade na interpretação da norma, pois existe espaço de possibilidades em que o intérprete está livre para decidir ${ }^{30}$. Nesse sentido, Dworkin aponta que na solução dos casos difíceis pela teoria do positivismo jurídico, em que a ação judicial não pode ser submetida a uma regra clara de direito, o intérprete tem o poder discricionário para decidir o caso de uma maneira ou de outra e que pode ser inadequada ao caso aplicado ${ }^{31}$.

Todavia, vale salientar que a abordagem hermenêutica deve se sintonizar

${ }^{26}$ DOMINGUES, Estevão. Legitimação constitucional dos tributos e o princípio da capacidade contributiva. Revista Dialética de Direito Tributário, São Paulo, n. 192, set, 2011, p. 23-25.

${ }^{27}$ ÁVILA. Humberto. Sistema constitucional tributário. 3.ed. São Paulo: Saraiva, 2008, p. 318.

28 SOUSA JÚNIOR, Mamede Rodrigues de. Princípio da vedação ao confisco: uma interpretação hermeneuticamente adequada e crítica à jurisprudência do Supremo Tribunal Federal. 2015. Disponível em: https://scholar.google.com.br/. Acesso em: 1 set. 2016.

${ }^{29}$ BOBBIO, Norberto. O positivismo jurídico: lições de filosofia do direito. São Paulo: Ícone, 1995, p. 147.

${ }^{30}$ STRECK, Lenio Luiz. O pós-positivismo e os propalados modelos de juiz (Hércules, Júpiter e Hermes): dois decálogos necessários. Revista de Direitos e Garantias Fundamentais, Vitória, n. 7, p. 19, jan.jun. 2010.

${ }^{31}$ DWORKIN, Ronald. Levando os direitos a sério. São Paulo: Martins Fontes, 2002, p. 127. 
com a democracia, preservando a defesa dos direitos e garantias constitucionais, devendo o ordenamento jurídico ser usado com integridade, honestidade, não havendo espaço para o relativismo, ou melhor, o intérprete não pode levar em consideração apenas o seu juízo e ideia, ou o que melhor lhe convier, mas sempre se certificar de todas as maneiras possíveis de que a interpretação é a melhor e mais acertada para o caso.

Desse modo, para buscar a resposta mais adequada à questão jurídica, o intérprete deve buscar informações na história e na tradição autêntica que, segundo Streck, a tradição do verdadeiro 'ser' da Constituição e de seus desdobramentos jurídico-políticos, a exemplo da igualdade, da redução da pobreza, da função social da propriedade, do respeito aos direitos humanos fundamentais, dentre outros ${ }^{32}$.

Corroborando esse entendimento, Grau enuncia que

A interpretação e a aplicação do texto constitucional no estado social de direito se tornam mais difíceis e controversas a começar pela multiplicação de suas ações direcionadas à conciliação dos interesses da sociedade e dos agentes econômicos, tornando o direito instrumento de efetivação de políticas públicas. Dessa forma, o direito carece de padrões determinantes fundados em preceitos constitucionais para solução de interesses opostos. ${ }^{33}$

Nessa linha de raciocínio, Dworkin considera que

Os princípios jurídicos como a exigência de justiça, equidade ou moralidade, e não a política de favorecer uma conjuntura de governo, econômica ou social desejável. Representam uma condição moral de impedir o comprometimento das necessidades básicas e do mínimo de existência à dignidade humana. Desse modo, o tributo que se amolda à conjuntura política e estar condizente com a moralidade da sociedade não viola o princípio da vedação ao confisco. ${ }^{34}$

Nesse sentido, a ação de tributar deve se harmonizar com o Estado democrático de Direito, em que prevaleça a vontade da sociedade e não o interesse de grupos econômicos e, se necessário, com a prevalência dos princípios

\footnotetext{
$\overline{32}$ STRECK, Lenio Luiz. Hermenêutica jurídica em crise. Porto Alegre: Livraria do Advogado, 2011, p. 345-347.

33 GRAU, Eros Roberto. A ordem econômica na Constituição de 1988. 14. ed. São Paulo: Malheiros, 2010, p. 164.

${ }^{34}$ DWORKIN, Ronald. Levando os direitos a sério. São Paulo: Martins Fontes, 2002, p. 36.
} 
constitucionais garantidores da ordem social para excluir regras destoantes dos interesses da coletividade e violadoras da ordem constitucional. Diante dos fatos postos, indaga-se qual o entendimento da Suprema Corte brasileira quanto à amplitude do princípio constitucional da vedação ao confisco tributário?

\section{A VISÃO DO STF QUANTO À AMPLITUDE DO PRINCÍPIO DA VEDAÇÃO AO CONFISCO}

As decisões do Supremo Tribunal Federal (STF) são importantes, pois influenciam no controle difuso de constitucionalidade brasileiro, de competência dos órgãos do poder judiciário, bem como do próprio STF por meio do recurso extraordinário, previsto no inciso III, do art. 102 da Constituição brasileira de 1988. Em relação ao controle concentrado de constitucionalidade, dá-se pelas ações direta de inconstitucionalidade e ações declaratórias de constitucionalidade da norma julgada (alínea "a", inciso I, art. 102), com apreciação pela Supremo Corte ${ }^{35}$.

De outro modo, as multas objetivam coibir os atos tributários ilícitos, tanto por descumprimento da obrigação principal como acessória, previstas na legislação. Os valores podem ser expressivos e superiores ao valor do tributo quando relativos a multas em que se caracteriza o dolo ou má-fé. Para Machado, as multas têm suposições antecipadas da prática do ato ilícito e isto garante que não sejam consideradas confiscatórias. Equivale a não concordar com a prática de atos infracionais e intencionais ${ }^{36}$.

Com relação à quantificação do valor da multa com caráter de confisco, o Agravo Regimental no Agravo de Instrumento (AI) no 830.300 AgR-Segundo/SC, $1^{\text {a }}$ Turma, de relatoria do ministro Luiz Fux, julgamento em 06/12/2011, concluiu ser confiscatória a multa superior a duas vezes o valor do tributo. Assim, indicou-se um padrão de aferição com base no valor do tributo devido. Todavia, não existe entendimento geral harmônico sobre o assunto ${ }^{37}$.

Nas decisões examinadas pelo STF não há distinção de método para o tipo de multa aplicada, se moratória ou por infração à norma, demonstrada no

\footnotetext{
35 BRASIL. Constituição da República Federativa do Brasil de 1988. Brasília, DF: Poder Executivo. 1988.

36 MACHADO, Hugo de Brito. Os princípios jurídicos da tributação na Constituição de 1988. São Paulo: Dialética, 2004, p. 118-119.

${ }^{37}$ BRASIL. Supremo Tribunal Federal. Agravo Regimental no Agravo de Instrumento (AI) $\mathrm{n}^{\circ} 830.300 \mathrm{AgR}-$ Segundo/SC, $1^{\text {a }}$ Turma, de relatoria do Ministro Luiz Fux, julgamento em 06/12/2011. Disponível em: http:// www.stf.jus.br. Acesso em: 5 fev. 2018.
} 
julgamento do Agravo Regimental AI n ${ }^{0} 539.833$ MG/AgR, $2^{\text {a }}$ Turma, relator ministro Joaquim Barbosa, DJe de 28/05/2010, em que se registrou não haver distinção entre os vários tipos de multa administrativa, não importando se a violação foi a legislação tributária ou urbanística ${ }^{38}$. Todavia, o entendimento da aplicação do princípio da vedação ao confisco às multas se admite desde da Medida Cautelar em Ação Direta de Inconstitucionalidade (ADI) $n^{0} 1.075$ MC/DF - Distrito Federal, Tribunal Pleno, relator ministro Celso de Mello, de 17/06/1998, e continua sendo controverso ${ }^{39}$.

A crítica contraria a decisão do STF, de forte argumentação, é no sentido de que as multas aplicadas por infração de atos ilícitos não podem ter o sentido de confisco, pois o propósito da multa é coibir ou frustrar o ilícito, a sonegação, a ilegalidade tributária. Sendo o valor da multa suportável estaria se prestigiando e viabilizando a ilicitude.

No contexto de vários posicionamentos divergentes no poder judiciário, em especial no STF, como também na doutrina, é que se mostra importante analisar qual a visão do STF quanto à amplitude do princípio constitucional da vedação ao confisco tributário. Para tanto, utilizaram-se as decisões do Supremo Tribunal Federal para saber se o Estado (sujeito ativo) observa ou não o princípio da vedação ao confisco ao instituir normas para o cumprimento das obrigações tributárias.

As decisões foram obtidas no site eletrônico do STF, via internet, em pesquisa da jurisprudência livre, no período de outubro de 1988, início da Constituição brasileira de 1988, até janeiro de 2018, verificando apenas os julgados onde constavam o termo "vedação ao confisco" e que tratavam de impostos, contribuições sociais, taxas, execução fiscal, multas, depósito judicial e empréstimo compulsório, excluindo os demais, como os valores de restituição, pelo motivo de não fazerem parte ou de terem resultados insignificantes para a pesquisa..

Os resultados foram tabulados onde constam as quantidades de decisões favoráveis e desfavoráveis, constantes das decisões em Recurso Extraordinário (RE), Ação Civil Originária (ACO), Ação Direta de Inconstitucionalidade (ADI) e Agravo de Instrumento (AI). Nas demais ações como Ação Declaratória de Constitucionalidade (ADC), Arguição de Descumprimento de Preceito Fundamental (ADPF), Reclamação Constitucional (Rcl); o termo "vedação ao confisco" relacionados a impostos,

\footnotetext{
${ }_{38}$ BRASIL. Supremo Tribunal Federal. Agravo de Instrumento AI 539.833 AgR., $2^{\text {a }}$ Turma, relator Min. Joaquim Barbosa, j. 20 abr. 2010, DJ-e 27 mai. 2010. Disponível em: http://www.stf.jus.br. Acesso em: 5 fev. 2018.

${ }^{39}$ BRASIL. Supremo Tribunal Federal. Medida Cautelar em Ação Direta de Inconstitucionalidade (ADI) $n^{0} 1.075$ MC/DF - Distrito Federal, Tribunal Pleno, relator Ministro Celso de Mello, de 17/06/1998. Disponível em: http://www.stf.jus.br. Acesso em: 5 fev. 2018.
} 
contribuições sociais, taxas, execução fiscal, multas, depósito judicial, empréstimo compulsório e depósito judicial; não foram encontrados e/ou não tinham relação direta com o tema e com a pesquisa proposta, como exemplo eventuais questionamentos sobre valores de restituição devidos ou não.

Quanto à análise de dados obtidos na pesquisa para o Sujeito Ativo/Estado/ Poder Público (S. A.) e Sujeito Passivo/Contribuinte/Particular (S. P.), têm-se que foram analisadas 59 decisões do Supremo Tribunal Federal, quanto à amplitude do princípio da vedação ao confisco, no termo pesquisado "vedação ao confisco". Os resultados foram extraídos das decisões do Pleno, $1^{\text {a }}$ Turma e $2^{\mathrm{a}}$ Turma do STF.

No Tribunal Pleno do STF, foram analisadas 13 decisões, sendo cinco favoráveis ao Sujeito Ativo e oito favoráveis ao Sujeito Passivo. O principal sucesso do Sujeito Ativo foi a Contribuição Provisória sobre Movimentação Financeira (CPMF), no quantitativo de três decisões. O principal sucesso do Sujeito Passivo foi a Execução Fiscal, com duas, e Contribuição para a Seguridade Social, com duas. Ressalta-se que das oito decisões favoráveis ao contribuinte pelo Tribunal Pleno, quatro são $\mathrm{ADIs}$ cujas normas foram consideradas inconstitucionais, reportando a assuntos como Contribuição para Seguridade Social, multa, CPMF e taxa judiciária, correspondendo a 50\% do total do êxito das ações.

Na Primeira Turma do STF, analisaram-se 21 decisões, sendo 14 favoráveis ao Sujeito Ativo e sete favoráveis ao Sujeito Passivo. O principal sucesso do Sujeito Ativo foi a multa legal e moratória com seis e do Sujeito Passivo foi a multa confisco com três e por inconstitucionalidade com uma.

Na Segunda Turma do STF, foram analisadas 25 decisões, sendo 19 favoráveis ao Sujeito Ativo e seis favoráveis ao Sujeito Passivo. O principal sucesso do Sujeito Ativo foi a CPMF, com seis, e Multa Legal com quatro, contra o principal sucesso do Sujeito Passivo que foi a multa com efeito confiscatório, com cinco.

No STF, foram 38 decisões a favor do Estado (Sujeito Ativo) e 21 decisões a favor do Sujeito Passivo (Contribuinte).

Em relação às decisões, a mais favorável para o Estado (Sujeito Ativo) foi a multa legal e a multa moratória, com dez decisões favoráveis, que conforme o STF, não foi classificada como confisco, vez que aplicada norma de acordo com a legislação e respeitado o princípio constitucional de vedação ao confisco.

Das decisões analisadas para o Sujeito Passivo (contribuinte) a mais favorável foi a multa confiscatória, com nove decisões favoráveis, seguida do excesso de 
execução fiscal e cobrança indevida para a Seguridade Social com quatro decisões.

Ressalta-se que na sequência das decisões mais favoráveis para o Sujeito Passivo, com igual quantidade de decisões, ficou a CPMF, com nove, entretanto, o tributo que iniciou com a lei $\mathrm{n}^{0}$ 9.311, Diário Oficial de 25/10/1996, com o objetivo de direcionar recursos para a saúde, prorrogado várias vezes, encerrou-se em outubro 2007, quando a Câmara Federal dos Deputados fez a proposta de extensão até 2011, todavia o Senado Federal rejeitou a sugestão $0^{40}$.

\section{CONSIDERAÇÕES FINAIS}

O princípio constitucional da vedação ao confisco deve se integrar ao Estado democrático de Direito, que reconhece da dignidade da pessoa e garante os direitos à liberdade, à igualdade, à autonomia, à propriedade e ao mínimo existencial. A solidariedade e a responsabilidade de todos devem prevalecer para se atingir os objetivos do Estado social. Para isso, há necessidade de recursos financeiros, que devem ter origem de contribuição solidária de todos os membros da sociedade, conforme a capacidade contributiva ou econômica, com o objetivo de custear a máquina estatal.

Nesse sentido, a tributação é fator de repartição de riqueza, redução de desigualdade social e econômica, bem como responsável pelo progresso humano. Todavia, a vedação ao confisco deve impor limites ao Estado e reprovar os excessos da tributação defendendo a dignidade do contribuinte, a função social da propriedade e o mínimo existencial para a sobrevivência da pessoa.

Diante dos fatos, analisou-se a visão do STF quanto à amplitude do princípio constitucional da vedação ao confisco tributário, por intermédio das decisões da Suprema Corte contidas no site eletrônico da própria entidade.

Diante dos resultados, pôde-se concluir que são poucos os processos judiciais demandando sobre o princípio da vedação ao confisco em relação às ações tributárias no STF, considerada a quantidade de processos que foram julgados relativos a outros assuntos tributários.

Em relação ao levantamento dos principais argumentos questionados pelos contribuintes e decididos pelo STF, quanto à ação do poder público (Sujeito Ativo) e ao respeito ao princípio constitucional da vedação ao confisco, concluiu-se

$\overline{40}$ BRASIL. Senado Federal. Senado noticias. Disponível em: < http://www12.senado.leg.br/noticias/entenda-oassunto/cpmf. >. Acesso em: 6 out. 2016. 
que a maior demanda foram as multas tributárias, consideradas de aplicação legal, indicando que estão atendendo ao princípio constitucional da vedação ao confisco, seguida da CPMF, extinta em 2007.

Conforme entendimento pelo STF quanto à amplitude ou ao respeito pelo poder público ao princípio constitucional à vedação ao confisco, das 59 decisões registradas, concluiu-se que $64,41 \%$ das decisões são favoráveis ao Estado (Sujeito Ativo), representando 38 decisões, contra 35,59\%, correspondendo a 21 decisões que entenderam que não foi respeitado o princípio constitucional.

Outras conclusões a registrar são a influência do positivismo jurídico ainda influente nas decisões e a considerável desobediência ao princípio da vedação ao confisco pelo Estado, em relação às multas tributárias. Sugere-se que o contribuinte (Sujeito Passivo) recorra mais ao STF, questionando a prevalência da ponderação dos princípios constitucionais sobre as regras legais nos casos de conflitos, com propósito de reduzir os excessos do Estado na aplicação da norma tributária, e no sentido de retomar os debates jurídicos em busca da efetiva vedação ao confisco e da proteção ao mínimo existencial e à dignidade do contribuinte.

\section{REFERÊNCIAS}

ALEXY, Robert. Teoria dos direitos fundamentais. 2. ed. São Paulo: Malheiros, 2008.

ÁVILA. Humberto. Sistema constitucional tributário. 3. ed. São Paulo: Saraiva, 2008.

BALEEIRO. Aliomar. Limitações constitucionais ao poder de tributar. 7. ed. Rio de janeiro: Forense, 2006.

BARROSO, Luís Roberto; BARCELLOS, Ana Paula de. O começo da história. A nova interpretação constitucional e o papel dos princípios no direito brasileiro. Revista de direito administrativo, v. 232, p. 141-176, 2003. Disponível em: https://scholar. google.com.br/. Acesso em: 19 fev. 2018.

BOBBIO, Norberto. Liberalismo e democracia. 6. ed. Brasiliense: São Paulo, 1994.

BOBBIO, Norberto. O positivismo jurídico: lições de filosofia do direito. São Paulo: Ícone, 1995. 
BRASIL. Constituição da República Federativa do Brasil de 1988. Brasília, DF: Poder Executivo. 1988.

BRASIL. Lei $\mathrm{n}^{\mathrm{O}}$ 5.172, de 25 de outubro de 1966. Código tributário Nacional. Brasília, DF: Poder Executivo. 1966.

BRASIL. Senado Federal. Senado noticias. Disponível em: http://www12.senado.leg. br/noticias/entenda-o-assunto/cpmf. Acesso em: 6 out. 2016.

BRASIL. Supremo Tribunal Federal. Agravo Regimental no Agravo de Instrumento (AI) $\mathbf{n}^{\mathbf{0}}$ 830.300 AgR-Segundo/SC, $1^{\text {a }}$ Turma, de relatoria do Ministro Luiz Fux, julgamento em 06/12/2011. Disponível em: https://tt.jusbrasil.com.br/ jurisprudencia/21273021/segundo-agreg-no-agravo-de-instrumento-ai-830300-scstf/inteiro-teor-110301667. Acesso em: 5 fev. 2018.

BRASIL. Supremo Tribunal Federal. Agravo de Instrumento AI 539.833 AgR., $2^{\mathrm{a}}$ Turma, relator Min. Joaquim Barbosa, j. 20 abr. 2010, DJ-e 27 mai. 2010. Disponível em: http://www.stf.jus.br. Acesso em: 5 fev. 2018.

BRASIL. Supremo Tribunal Federal. Medida Cautelar em Ação Direta de Inconstitucionalidade (ADI) $\mathbf{n}^{\mathbf{0}}$ 1.075 MC/DF - Distrito Federal, Tribunal Pleno, relator Ministro Celso de Mello, de 17/06/1998. Disponível em: http://www.stf.jus.br. Acesso em: 5 fev. 2018.

CALIENDO, Paulo. Reserva do possível, direitos fundamentais e tributação. In: SARLET, Ingo Wolfgang: TIMM, Luciano Benetti (org.). Direitos fundamentais: orçamento e "reserva do possível. 2. ed. Porto Alegre: Livraria do Advogado, 2013.

CASSONE, Vittorio. Direito tributário. 11. ed. São Paulo: Atlas, 1999.

CHIMENTI, Ricardo Cunha. Direito tributário. São Paulo: Saraiva, 2001.

SOUZA, Carolina Romero de; DIAS, Eduardo Rocha. Nova hermenêutica constitucional: a valorização dos princípios na interpretação constitucional da previdência social brasileira. Revista Direito \& Dialogicidade, v. 3, n. 1, 2013.

DOMINGUES, Estevão. Legitimação constitucional dos tributos e o princípio da capacidade contributiva. Revista Dialética de Direito Tributário, São Paulo, n. 192, set, 2011. 
DWORKIN, Ronald. Levando os direitos a sério. São Paulo: Martins Fontes, 2002.

DWORKIN, Ronald. O império do direito. São Paulo: Martins Fontes, 2007.

GRAU, Eros Roberto. A ordem econômica na Constituição de 1988. 14. ed. São Paulo: Malheiros, 2010.

HORVATH, Estevão. O princípio do não-confisco no direito tributário. São Paulo: Dialética, 2002.

MACHADO, Hugo de Brito. Os princípios jurídicos da tributação na Constituição de 1988. São Paulo: Dialética, 2004.

SANTOS, Boaventura de Sousa; FERREIRA, Silva. A reforma do Estado-Providência entre globalizações conflituantes. In: Pedro Hespanha e Graça Carapinheiro (org.). Risco social e incerteza: pode o Estado social recuar mais?. Porto, Afrontamento, 2003. Disponível em: https://scholar.google.com.br/. Acesso em: 19 fev. 2018.

SARLET, Ingo Wolfgang. Dignidade da pessoa humana e direitos fundamentais na Constituição Federal de 1988. 9. ed. rev. atual. Porto Alegre: Livraria do Advogado, 2012.

SOUSA JÚNIOR, Mamede Rodrigues de. Princípio da vedação ao confisco: uma interpretação hermeneuticamente adequada e crítica à jurisprudência do Supremo Tribunal Federal. 2015. 160f. Dissertação (Mestrado em Direito) - Universidade do Vale do Rio dos Sinos, São Leopoldo, RS, 2015.

STRECK, Lenio Luiz. O pós-positivismo e os propalados modelos de juiz (Hércules, Júpiter e Hermes): dois decálogos necessários. Revista de Direitos e Garantias Fundamentais, Vitória, n. 7, p. 19, jan./jun. 2010.

STRECK, Lenio Luiz. Hermenêutica jurídica em crise. Porto Alegre: Livraria do Advogado, 2011.

TEIXEIRA, Anderson Vichinkeski. O tributo na formação histórica do Estado moderno. Revista de Direito Tributário da APET, São Paulo, v. 12, p. 13-44, 2007.

TEPEDINO, Gustavo. Normas constitucionais e relações de direito civil na experiência brasileira. Temas de direito civil. t. 2. Rio de Janeiro: Renovar, 2006. 


\section{ZILVETI, Fernando Aurélio. Princípios de direito tributário e a capacidade contributiva. São Paulo: Quatier Latin, 2004.}

Recebido em: 24/09/2018

Aceito em: 05/02/2019

\section{Anexos:}

Quadro 1. STF - Tribunal Pleno

\begin{tabular}{|c|c|c|c|c|c|}
\hline Instrumento & TRIBUTO & Vencedor & DECISÃO & ALEGAÇÃO & QTDE \\
\hline RE & ICMS-Bem importado & S. P. & Negado & Não incidência imposto - II & 1 \\
\hline ACO & Execução Fiscal & S. P. & Não conhecido & Incompetência do STF & 2 \\
\hline ADI & CPMF & S. A. & Prejudicada & Inconstitucionalidade & 1 \\
\hline ADI & Contrib. p/ Seg. Social & S. P. & Provido & Inconstitucionalidade & 2 \\
\hline ADI & CPMF & S. A. & Indeferido & Inconstitucionalidade & 2 \\
\hline ADI & Multa & S. P. & Deferido & Inconstitucionalidade & 1 \\
\hline ADI & CPMF & S. P. & Deferida & Inconstitucionalidade & 1 \\
\hline ADI & Depósito Judicial & S. A. & Indeferida & Inconstitucionalidade & 1 \\
\hline ADI & Taxa Judiciária & S. P. & Indeferida & Inconstitucionalidade & 1 \\
\hline ADI & Contrib. p/ Seg. Social & S. A. & Indeferida & Inconstitucionalidade & 1 \\
\hline Total & & & & & 13 \\
\hline
\end{tabular}

Fonte: Elaboração própria do autor com base nas decisóes do site do STF.

Quadro 2. STF - Primeira Turma

\begin{tabular}{|c|c|c|c|c|c|}
\hline Instrumento & TRIBUTO & Vencedor & DECISÃO & ALEGAÇÃO & QTDE \\
\hline ARE & Multa & S. P. & Negado & Efeito confiscatório & 1 \\
\hline ARE & Multa & S. P. & Negado & Inconstitucionalidade & 1 \\
\hline ARE & Multa & S. A. & Negado & Falta de prequestionamento & 1 \\
\hline AI & Multa & S. P. & Provido & Efeito confiscatório & 1 \\
\hline AI & Alíq. Prev. Serv. Púb. & S. P. & Negado & Efeito confiscatório & 1 \\
\hline AI & Multa & S. A. & Negado & Inconstitucionalidade & 2 \\
\hline AI & Multa & S. A. & Negado & Efeito confiscatório & 1 \\
\hline AI & Multa & S. A. & Negado & ISS - arrend. mercantil & 1 \\
\hline AI & CPMF & S. A. & Negado & Constitucionalidade & 2 \\
\hline RE & Taxa Florestal & S. A. & Não conhecido & Efeito confiscatório & 1 \\
\hline RE & Alíq. Prev. Serv. Púb. & S. P. & Negado & Efeito confiscatório & 1 \\
\hline RE & ICMS & S. A. & Negado & Ônus da prova & 1 \\
\hline RE & Multa & S. P. & Negado & Efeito confiscatório & 1 \\
\hline RE & ICMS Correç. Monet. & S.A. & Provido & Conversão em Unidades Fiscais & 1 \\
\hline RE & IRPJ - Correç. Monet. & S.A. & Negado & Não cabe à norma & 1 \\
\hline RE & CPMF & S. A. & Negado & Inconstitucional & 1 \\
\hline RE & IPI - Multa Moratória & S.A. & Não conhecido & Não Abusividade & 1 \\
\hline RE & ICMS & S. A. & Não conhecido & Inconstitucionalidade & 1 \\
\hline RE & ICMS & S. P. & Provido & Extensão de Base & 1 \\
\hline
\end{tabular}




\begin{tabular}{|c|c|c|c|c|c|}
\hline Instrumento & TRIBUTO & Vencedor & DECISÃO & ALEGAÇÃO & QTDE \\
\hline Total & & & & & 21 \\
\hline
\end{tabular}

Fonte: Elaboração própria do autor com base nas decisôes do site do STF.

Quadro 3. STF - Segunda Turma

\begin{tabular}{|c|c|c|c|c|c|}
\hline Instrumento & TRIBUTO & Vencedor & DECISÃO & ALEGAÇÃO & QTDE \\
\hline ARE & Multa & S. A. & Negado & Inviabilidade do recurso & 1 \\
\hline RE & Multa & S. P. & Negado & Efeito confiscatório & 4 \\
\hline RE & Multa & S. P. & Negado & Instrução probatória & 1 \\
\hline RE & Alíq. Prev. Serv. Púb. & S. P. & Negado & Efeito confiscatório & 1 \\
\hline RE & Multa & S. A. & Negado & Deficiência probatória & 3 \\
\hline RE & Majoração Alíquota & S. A. & Negado & Constitucionalidade & 1 \\
\hline AI & II & S. A. & Negado & Confisco do Bem & 1 \\
\hline AI & Taxa Florestal & S. A. & Negado & $\begin{array}{c}\text { B. Cálculo distinta da B. } \\
\text { Cálculo do ICMS }\end{array}$ & 1 \\
\hline RE & CPMF & S. A. & Negado & Inconstitucionalidade & 3 \\
\hline RE & $\begin{array}{c}\text { Emprést. Compulsório } \\
\text { S/ Energia Elétrica }\end{array}$ & S. A. & Negado & Inconstitucionalidade & 2 \\
\hline RE & INSS - Inativos & S. A. & Negado & Inconstitucionalidade & 2 \\
\hline RE & IOF-Venda de Ação & S. A. & Negado & $\begin{array}{l}\text { Alíquota não } \\
\text { confiscatória }\end{array}$ & 1 \\
\hline AI & CPMF & S. A. & Negado & Inconstitucionalidade & 3 \\
\hline AI & ICMS & S. A. & Negado & Inconstitucionalidade & 1 \\
\hline Total & & & & & 25 \\
\hline
\end{tabular}

Fonte: Elaboração própria do autor com base nas decisóes do site do STF. 